\title{
Architecture and the Place of Difficult Memory: Documentation Center Nazi Party Rally Grounds in Nuremberg, Germany
}

\author{
RUMIKO HANDA \\ University of Nebraska-Lincoln
}

\begin{abstract}
How can architectural design assist in making the past present in meaningful ways when applied to pre-existing buildings that carry particularly notable and troubling pasts? The paper focuses on the Documentation Center housed in the former Congress Hall on Nazi Party Rally Grounds in Nuremberg, Germany, for which Austrian architect Günther Domenig won an invitational competition in 1998. On-site analysis and archival study reveal memory-inducing mechanisms of designation, formal characteristics, physical trace, and memento.
\end{abstract}

\section{INTRODUCTION}

How can architectural design assist in making the past present in meaningful ways when applied to pre-existing buildings that carry particularly notable and troubling pasts? In order to address this question, I will investigate the Documentation Center housed in the former Congress Hall on Nazi Party Rally Grounds in Nuremberg, Germany, designed by Austrian architect Günther Domenig. Here, permanent exhibit titled "Fascination and Terror" presents the rise of the National Socialist Party, the Fuhler cult, Nuremberg as the city of the annual Party Rally, World War II and the Holocaust, and the Nuremberg Trials and after 1945. This architectural piece is ideal for the question being posed for a number of reasons. First, the design was applied to a pre-existing building at which significant historical events took place. Second, remembering the Nazi past is not just worthy but a civic duty. Third, the Center addresses an extremely difficult past. While it is very difficult and painful to recall an experience in which one was the victim, I use the term extremely difficult to mean the past in which one was, or the people one closely associates with were, the perpetrator(s). Additionally, the architect's personal background makes this case important: Domenig struggled with his own anti-Semitism, whose father was a party member killed by the resistance, and who, when young, had a hard time reconciling with the fact that many important architects were Jewish. ${ }^{1}$ I will present an analysis of Domenig's design, through on-site investigation and archival study at the Architecture Center, Vienna, which, after the architecct's death, houses materials from Domenig's office. ${ }^{2}$

But first, I will place my question in the context of current issues and events in the United States. 2017 was the year the issues surrounding Confederate monuments intensified. A chain of events started in June 2015, in which nine parishioners were killed by a white supremacist at the Emanuel African Methodist Episcopal Church in Charleston, South Carolina. Immediately afterwards, New Orleans Mayor Mitch Landrieu called for the removal of four Confederate statues from public spaces. On the 27th of the same month, Mayor Dwight C. Jones of Richmond, Virginia, published an opinion piece on the Confederate statues that line up on Monument Avenue of that city. ${ }^{3}$ In February, 2017, the City Council of Charlottesville, Virginia, voted to remove a statue of Robert E. Lee from a park, which subsequently in July was reamed Emancipation Park. On July 7, the Confederate flag came down on South Carolina's statehouse grounds. On August 12, violence broke between the protesters and counter-protesters, and a woman was killed by a white supremacist who drove the van into the crowd. Professional and academic organizations including the National Trust for Historic Preservation and the American Historical Association as well as individual scholars including Professor Del Upton, renowned historian of architecture at the University of California, Los Angeles, presented their positions concerning appropriate treatments of Confederate monuments - whether to destroy, remove, or keep them. ${ }^{4}$

Not only local communities but also Universities were confronted with the issues surrounding artefacts from the past. Harvard's Business School eliminated from its crest the image related to slavery, and John C. Calhoun's name was removed from one of Yale's residential colleges. Radcliffe Institute of Advanced Study at Harvard held a symposium titled "Universities and Slavery: Bound by History" in March of 2017. At the symposium, Hilary Beckles of the University of West Indies quoted one of the judges of the Nuremberg Trials: "We are walking into the desert, and somewhere out there is water. Let us go and find it." Beckles was using the passage to characterize the complexity of the issues involving universities' past relations to slavery. The key ethical conundrum is that obliterating the artifacts or their associations with the past does not eradicate the past itself and instead removes the artifacts' ability to remind us of the past and our chance to confront and understand it. Conversely, preserving artifacts alone does not yield productive discourse unless accompanied by a clear indication that the preservation of artifacts does not affirm the past actions. 


\section{BUILDINGS REPRESENTING THE PAST: MECHANISMS AT WORK}

Buildings, just as statues, crests, or namesakes, have a way of bringing the past into the present. This is important because experiences of the past often constitute impactful moments in everyday lives and allow a contemplation of existential meaning, but is often neglected by architectural professionals and critics because it lies outside the Vitruvian triad of aesthetic, functional, and structural virtues. It is important to understand the memory-inducing mechanisms of buildings, for they are sometimes similar but not always the same as those of statues, crests, or namesakes do. In an attempt to classify these mechanisms, I have borrowed some concepts from Charles Sanders Peirce and Hans George Gadamer, with some modifications. I have identified four distinct mechanisms: First, a building may commemorate a particular event or individual by being designated to do so. Second, it may refer to the time of its origin by way of its formal characteristics, or carrying a certain style. Third, it may recall an otherwise neglected past by bearing physical traces, just like the palimpsest, an animal hide used by monks as a writing surface, on which, an old writing, once washed out, has resurfaced. These three categories roughly correspond to Peirce's classification of signs, that are, respectively, symbol, icon, and index. ${ }^{5}$ Additionally, since we cannot ignore our common experiences that do not fall into any of the three, I have brought into discussion Gadamer's concept, that a building may also serve as a memento simply because an event took place there. ${ }^{6}$

Two important considerations need to be made, that, first, any particular building referring back to a past most likely than not carry not one but two or more of the above four categories. Secondly, a building's presentation of the past is ontological. In other words, individual perceptions of a building are subjective, and the building's objective traits or histories do not guarantee that the building turns into a place of memory for everybody. Because of this, I believe, there is a role that architectural design can play in assisting in making the past present in meaningful ways when applied to a pre-existing building that carries a notable and troubling past.

The City of Nuremberg's tie to the Nazi past is complex and multi-layered. First, the Race Laws, later known as the Nuremberg Laws, were announced there in 1935 during the Party Rally; Secondly, the propaganda newspaper Der Stürmer was published there by Julius Streicher, who led the Party's Franconian division; And thirdly, during 1945-1946 major Nazis responsible for the Holocaust were tried there at the so-called Nuremberg Trials. But above all, Nuremberg's dark past is rooted in it having been the place of the Nazi Party Rallies, which involved the entire city, physically and socially. Hermann Glaser, influential social historian and Nuremberg's culture minister since 1964, retrospectively noted: "'Eternal jubilation met the Führer of the Franconians when he appeared on Adolf Hitler Square. There was a storm of enthusiasm which subsided only after quite a while.' The overwhelming majority of the women and men of Nuremberg could have avoided this event without any danger of retaliation. Instead, they applauded these national criminals." ${ }^{7}$

The following section offers an analysis of Domenig's design, addressing the question of how architectural design can assist in making the past present in meaningful ways when applied to a pre-existing building that carry particularly notable and troubling pasts.

\section{DESIGNATIONAS A PLACE OF MEMORY}

It had taken half a century to designate the former Congress Hall as a place that recalls the City's involvement in Nazism. During that time, Nuremberg's citizens went through a number of ideological, political, and moral stances regarding the colossal material evidence of the City's involvement in the genocide. Denial of the past and willful forgetfulness were prevalent during 1950s and '60s, manifested in changing the name to Round Exhibition Building, referring only to the shape and the new purpose; shifting the focus to the City's medieval and Renaissance pasts manifested in the Castle and Albrecht Dürer House; and proposing destruction of the building. ${ }^{8}$ The desire to forget the past associated to the building also promoted demolition of the building, just as some people want to destroy Confederate monuments. In 1963, the Association of German Architects proposed the demolition of the building, for the reason that it "remains a contravention of the spirit of the new city. ... We have the responsibility to erase this sign and to sacrifice it." Additionally, they portrayed themselves as innocent victims, expounding that Nazism had come from outside Nuremberg, and that the City was a casualty of allied bombing.

There also were attempts at adapting the building to other mundane purposes. In addition to the above use as an exhibition hall, there were ideas to apply some substantial work to the building, for additional economic exploitation. Ideas included a football stadium (1955) and an event venue with covered courtyard (1958), which were not pursued for financial and structural reasons. But the notion that the trivial use would suppress the Nazi's monumental power gained philosophical support from Hannah Arendt's "Report on the Banality of Evil." During 1970s and '80s, profanation was promoted. The U-shaped building was used as a storage with annual rental income to the City. The Nuremberg Symphony gained the use of the southern end block. Since 1986 , the courtyard within the southern block was turned into the Serenadenhof, an open-air music venue. Other proposals included a drive-in cinema or an elderly people home.

Meanwhile, a new perspective was emerging. Influenced at least partly by Theodor W. Adorno, who in his lecture in 1959 rejected the contemporary catchphrase "working through the past" as misleading, observing that "its intention is to 


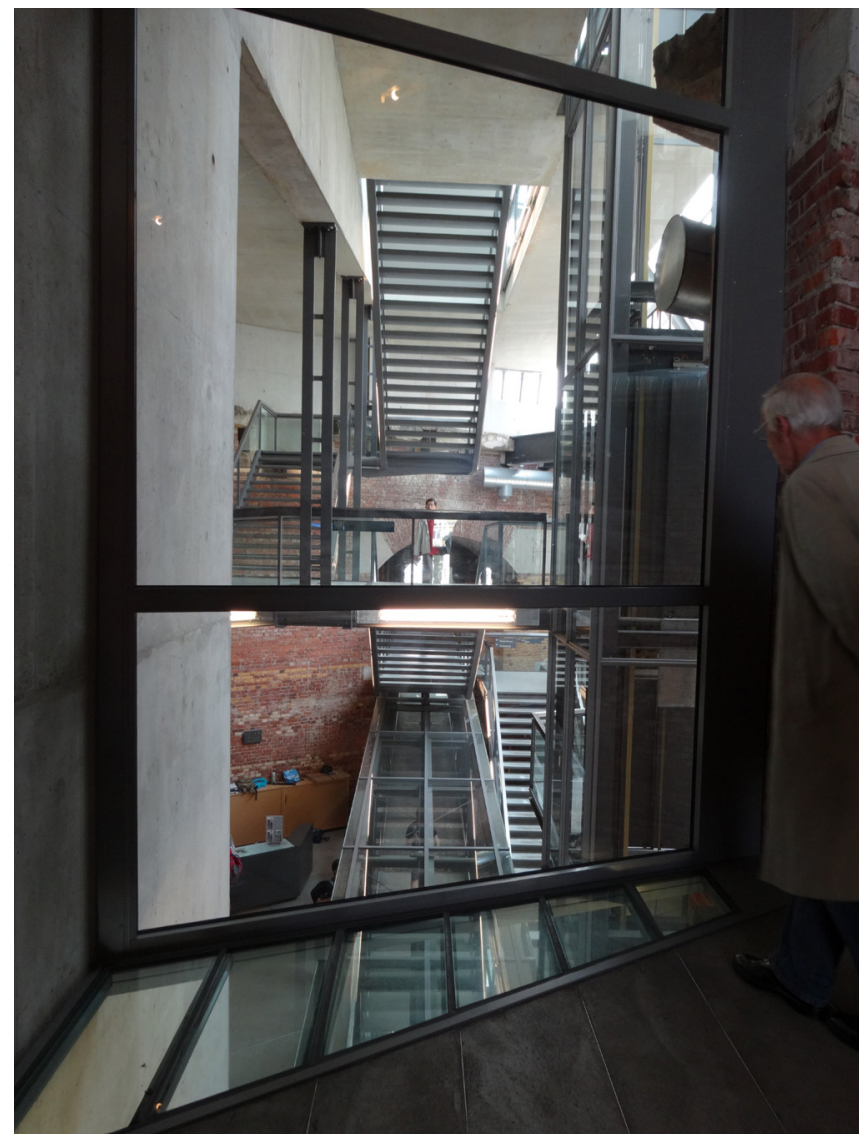

Figure 1: View of the Stake. Photo by Author.

close the books on the past and, if possible, even remove it from memory. ${ }^{10}$ Instead he promoted the kind of critical selfreflection Freudian theory called for in order to come to terms with the past. ${ }^{11}$ In 1985 an exhibition entitled "Fascination and Violence" was installed in the Zeppelin Stand, which was part of Rally Ground complex and designed by Albert Speer.

In 1987, strong opposition was raised against Nuremberg's businessmen's proposal to convert the building into a leisure center. This time, Michael Petzet, Conservator General of the Bavarian Conservation Department in Munich, a branch of the National Office for the Preservation of Monuments wrote to the City administration, stating that the building was the "most important testimony of the gigantomania of the National Socialism" and should be left unused, differentiating the Mahnmal, a critical statement about or a warning from the past, from the Denkmal, a mere reminder, or Ehrenmal, which honors someone or something from the past. ${ }^{12}$ The Association of Persecutees of the Nazi Regime also protested against the leisure center proposal. Some Nuremberg citizens also offered a proposal, along the line of Petzet, of leaving the courtyard to a planned decay, "to take care of its criminal world of thought."13

An additional ten years had to pass, before a board of trustees for a new documentation center was established in 1997, and in the following year, the City announced an invitational architectural competition for the Dokumentationszentrum Reichspartitagsgelände, to be housed in the uppermost floor of the northern end block. ${ }^{14}$ The City expected 100,000 annual visitors. ${ }^{15}$ Middle Bavarian and Federal Governments joined the City to fund the project, so did private sponsors and cultural foundations. Eight teams of architects were invited. ${ }^{16}$ The deadline was October 23, and the jury met on November 11. The first prize went to Günther Domenig from Graz, Austria. ${ }^{17}$

The designation of the former Congress Hall as a place of memory of the Nazi past was made possible by the memory culture and politics that gradually shifted in the City of Nuremberg and also in Germany. One can observe other documentation centers being recognized and designated around the same time period, including: Topography of Terror in Berlin, the House of Wansee Conference, in the suburb of Berlin.

\section{STANDING AGAINST THE NAZI PAST IN FORM}

The Documentation Center opened on November 4, 2001. The opening originally was planned for 2000, to coincide with the City's 950th anniversary; however, it was delayed by a year. Instead, they celebrating the topping of the building on November 15, 2000.

The most striking and pronounced of Domenig's design for the Documentation Center, acknowledged both by the architect himself and the community leaders, is the Pfahl, or stake, of glass and steel, which cuts diagonally through the orthogonal mass of the pre-existing building of stone, bricks, and concrete. The stake presents a stark contrast in forms and materials against the Nazi building. Explaining this design element, Domenig recalled touring the building for the first time in September, 1998: "During the visit, icy coldness came over me. The dust of the dead in the interior spaces and the architectural translation of the power - there were only right angles and axes." ${ }^{18}$ His idea was to destroy this "power" by cutting into it. ${ }^{19}$ The north end of the stake thrusts out of the polychrome marble building, providing a clearly marked entrance to the Documentation Center, visible from afar. In the entrance hall, the main stairs and the elevator, of steel and glass, are aligned with the stake, which lead visitors up to the exhibit floor. Once arriving upstairs, the visitors come onto the top of the stake, which forms a lookout to the front street and the entrance hall (figure 1). The floor here is of frost glass, making clear the notion of incision. After going through the exhibit sequence set in the dark and orthogonal rooms of bricks and concrete, visitors meet up with the stake at its other end, which provides a balcony over the courtyard. Visitors then return to the entrance hall, walking the full length of the stake and descending the full height of the floor. ${ }^{20}$

Formal contrast of the diagonal and the orthogonal can be found elsewhere in the Center. The new study center's auditorium hovers above the entrance hall, with its underside 


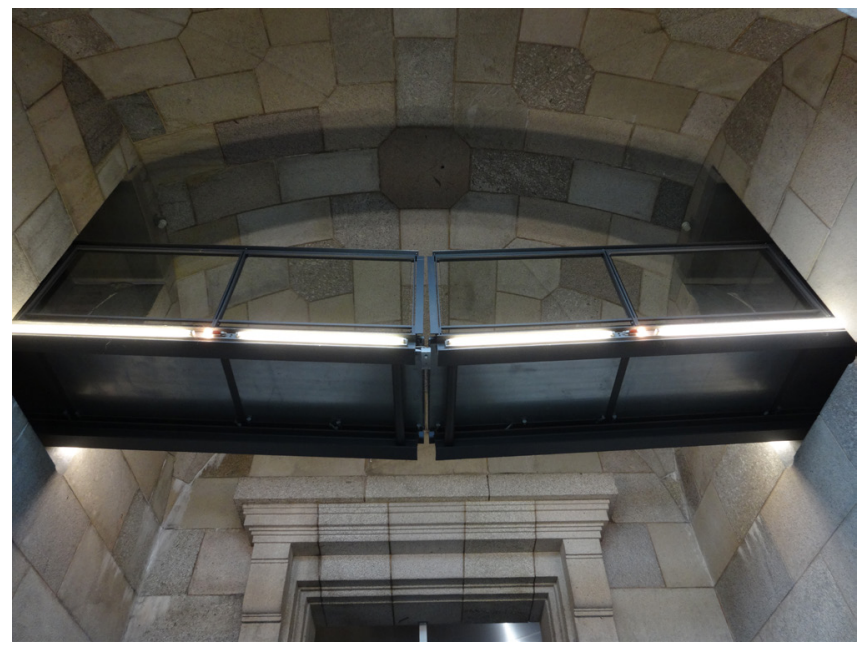

Figure 2: View of the Bridge. Photo by Author.

composed of diagonal planes. A bridge that crosses over the original entrance hall has a slight incline downward to the middle point of the span, which makes diagonal possible vertically (figure 2).

\section{DISPLAYING EXISTING SCARSAND INFLICTING NEW ONES}

Architectural criticisms of the Documentation Center often have focused on the formal and material contrast brought forth by the stake. However, Domenig's design accomplished much more to bring forth and confront the difficult past behind the former Congress Hall, making possible meaningful architectural experiences. The idea of treating the building not just a container of the exhibition but also an exhibit on its own as a trace of Nazi's actions did originate with the City. But it was the architect who understood the potential of physical trace. Domenig stated, "This task is exceptional. The exhibition ... is a 'remembrance memorial' in the truest sense of the words 'negative contemporary history.'"21 To start with, Domenig kept the exhibition spaces' ceilings unfinished, in the state of raw concrete slabs with sharp pointed metals still exposed. He also kept the raw brick interior walls, with irregular protrusions, which had been meant for later construction of additional walls.

While the ceilings and walls remained in its ruined state, the floors presented a design challenge, which Domenig successfully turned to an opportunity. For practical and safety reasons, they had to be finished. Domenig stated: "The existing rooms, their walls and ceilings, are largely preserved in their raw concrete or brick surface structure. The existing bear floors are provided with industrial floor coverings (sealed concrete screeds)." ${ }^{22}$ While Domenig's text does not go any further on this topic, a drawing in the Domenig Archive, dated January 19, 2000, and drawn by Gerhard Wallner of Domenig's office, shows how the floor finish was applied. The rough row surface of the existing floor was first leveled with mortar of 40

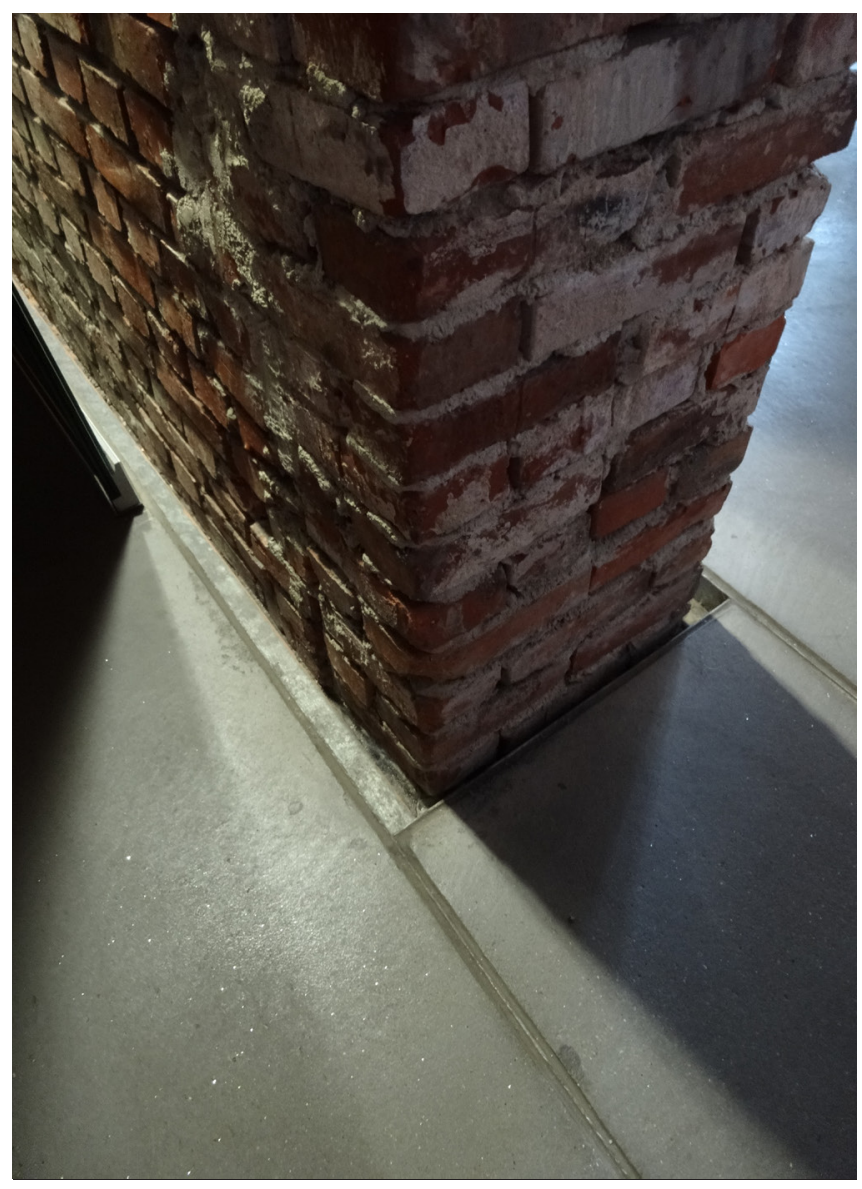

Figure 3: Raw wall and finished floor. Photo by Author.

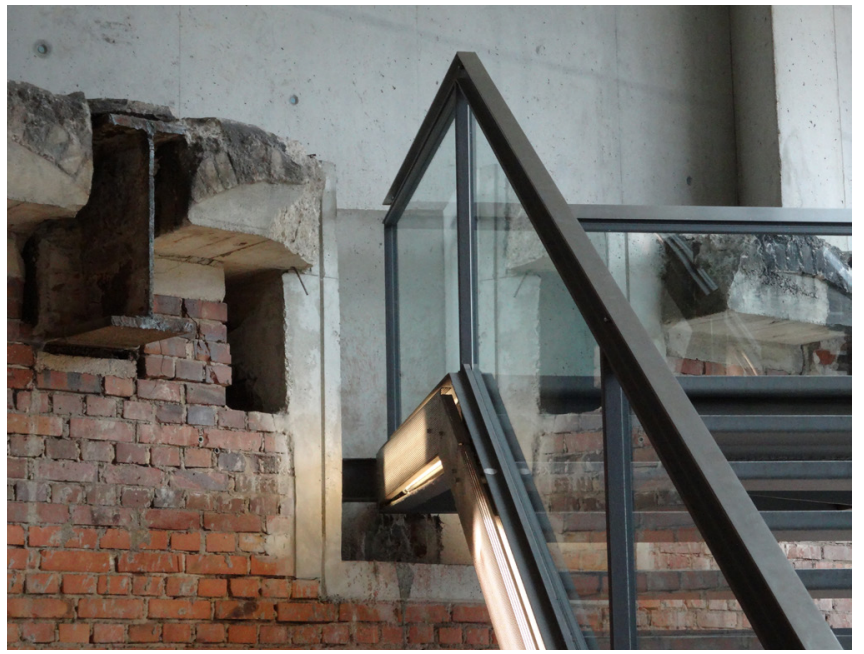

Figure 4: The corner of the stairs cutting into the existing brick wall. Photo by Author.

$\mathrm{mm}$ thickness, on which insulation of $40 \mathrm{~mm}$, foil, and heated floor of $70 \mathrm{~mm}$ were applied, and the surface was treated. To be noted for the present discussion is the treatment of the borders of the room. The drawing specifies a bent metal piece of either steel or aluminum of $120 \mathrm{~mm}$ tall and $60 \mathrm{~mm}$ wide along the joint between the wall and the floor, which created a gap of $60 \mathrm{~mm} \times 60 \mathrm{~mm}$ along the perimeter of the room. As 


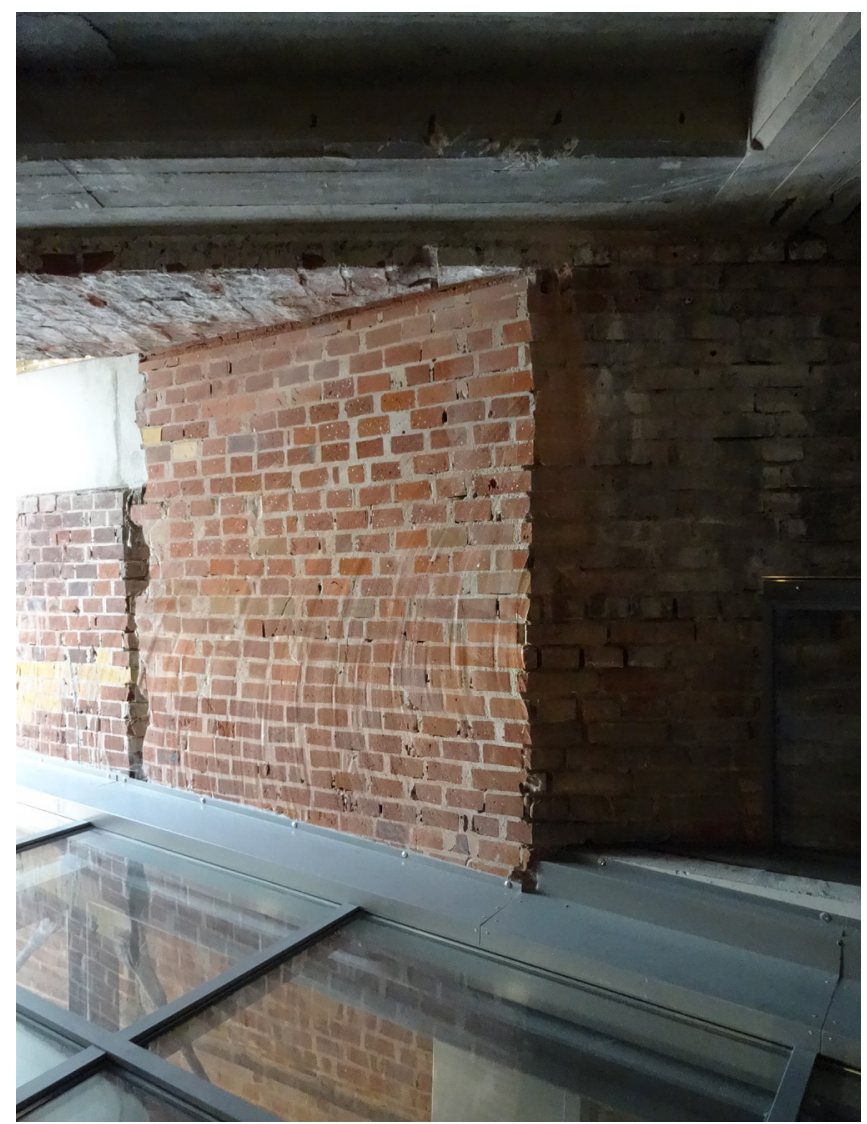

Figure 5: The physical trace of the circular saw is visible in the brick wall. Photo by Author.

a result, the new floor never touches the pre-existing column or wall, and clearly suggests the contemporary abhorrence toward the Nazi past (figure 3).

The architect's design strategy to confront the past by keeping new elements away from the existing fabric can be seen elsewhere. The stake and the bridge mentioned above stay detached from the pre-existing bricks and marble. In the entrance hall, this created an interesting detail, in which the corner of the stairs collides with the existing brick wall, bricks were cut into, and the supporting detail creates a visual appearance of the stairs never touching the brick wall (figure 4).

Inserting the stake, setting up a route through all the exhibit spaces, and placing a study center on top presented challenges at execution. At a number of locations existing walls or slabs had to be cut (figure 5). ${ }^{23}$ The architect made sure that the sections of the granite, bricks, concrete, and steel were left just as the saw left them, without finish or even polish. Visitors are presented the physical scars that the Center inflicted upon the Congress Hall, from the entrance and throughout the building. The physical traces therefore not only remind the visitors of the past, but also overtly presents their critical stance against the Nazi actions.

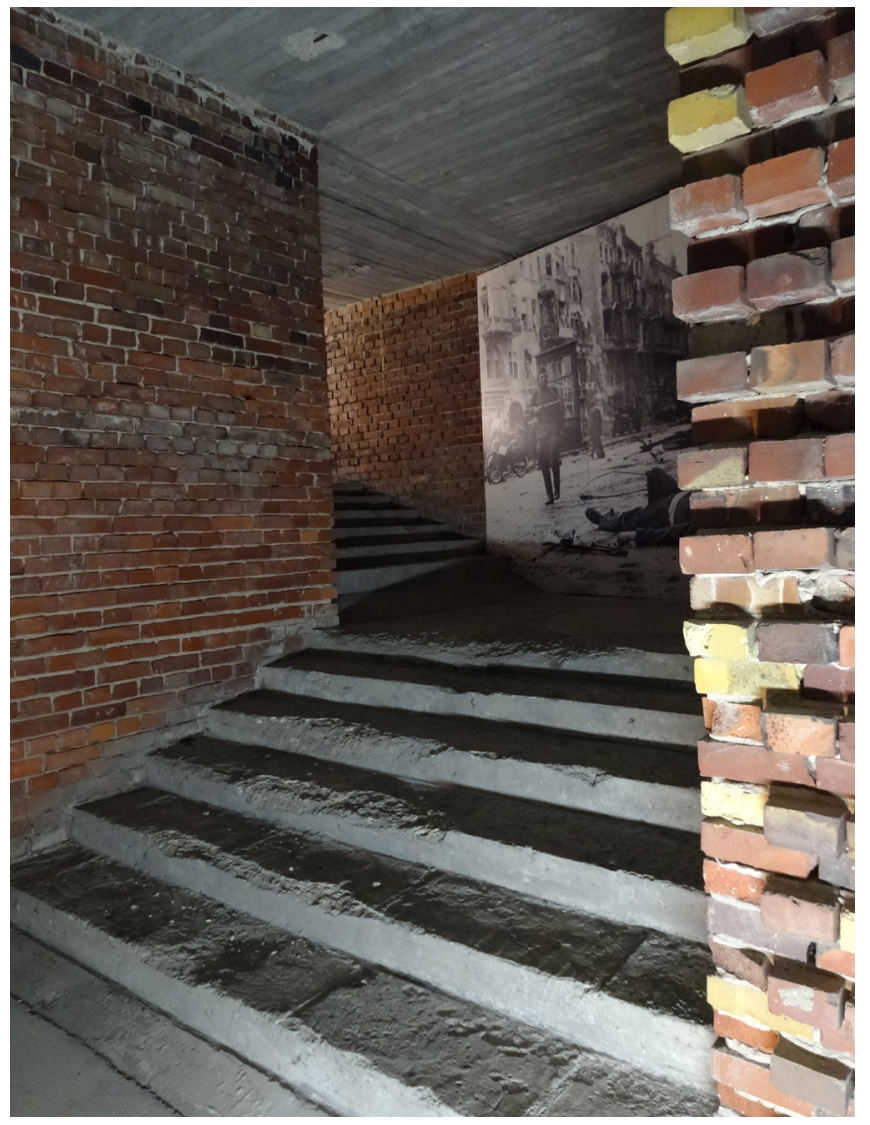

\section{QUASI-MEMENTO}

The memento by definition requires the person to have personally experienced the past being recalled. With those who experienced the Congress Hall during the Nazi era ageing, or already passed away, efforts were made to turn the former Congress Hall into a place of quasi-memento for the younger generations. First, the Center collected oral history. The community members willingly participated. In April 1998, four months before the competition was first announced, Gregor Schöllgen, Professor of Modern History at the University of Erlangen, who was involved in setting up the permanent exhibition, shared his pleasure that "many witnesses agreed to talk about their experiences." 24 The last stop on the visitors' route is dedicated to those records, including videos of elderly women recollecting them competing against each other on how many times they managed to have glimpses of the Fühler on a Rally day and of a man demonstrating a military salute, using his umbrella for a gun. Some other exhibition techniques to make the past experiences transferable are the use of large-scale photographs of war scenes or cut-outs of Nazi uniform-clad men standing in the middle of the exhibition space.

Architectural design also worked to trun the building into a quasi-memento. In the space near the end of the exhibit sequence, where the narrative is at the height of the horror of the War and the Holocaust, a a bridge is set up over the level difference of the floors, detached both from the floor 
and the walls of the Congress Hall. Here, horizontal layering of bricks protrudes and recedes significantly from one layer to the other. With the alternate hiding and revealing, the corner of the brick wall raises the visitors' curiosity into the space beyond. Domenig took advantage of the experientiaal effect of this wall detail. When the visitor reaches the corner, the full-scale photograph depicts a devastating scene of the war. (figure 6) Domenig allowed the architecture, the old and the new together, give out a warning to the future.

\section{CONCLUSION}

Nuremberg's Documentation Center, being tasked to show the causes and connections of the "criminal power exercise" of the Nazi state and to show its "violent consequences," 25 stands at a point in time, being a fruit of the decades of the struggles and efforts against the extremely difficult past, and the will to effectuate the past toward the future. Domenig commended the city of Nuremberg for having a clearly defined task of showing the more profound connections through exhibit, media, and training, and hoped that he was able to express these requirements architecturally. He hoped that the overall structure would become an extremely powerful and impressive experience. He tasked himself and all to realize the goal consistently and incorruptibly. $\mathrm{He}$, in his professional capacity, has tackled the task by inflicting wounds to the Nazi building, avoiding the touch, and creating the space of unease and foreboding: "It is satisfactory for me - through my creative potency and profession - to respond to this historical tragedy with hope." "I hope that I have succeeded in expressing these requirements architecturally." ${ }^{26}$

\section{ENDNOTES}

1 Günther Domenig, presentation script (November 15, 2000), Architecture Center Vienna (Az-W hereafter).

2 At Domenig's death of 2012, the office was succeeded by Gerhard Wallner, who had studied under Domenig at the Technical University in Graz, and had been working at Domenig since 1987. He directed the office from 1990 to 2000. In 2005 Wallner became CEO of the office of Architekten Domenig \& Wallner. Wallner in fact had heavy hand during the execution of the Documentation Center building. Many correspondences between the architect's office and on-site contractors bear his name.

3 Graham Moomaw, "Mayor Jones on Confederate Statues: 'Rather than Tearing Down, We Should Be Building Up,'” Richmond Times-Dispatch, June 27, 2015, http://www.richmond.com/news/local/city-of-richmond/ mayor-jones-on-confederate-statues-rather-than-tearing-down-we/article ac2e3115-d073-5e56-83b3-55dca3784e4c.html.

4 The National Trust for Historic Preservation (Stephanie Meeks, President and CEO), "Statement on Confederate Memorials: Confronting Difficult History | National Trust for Historic Preservation," June 19, 2017, https://savingplaces.org/press-center/media-resources/national-truststatement-on-confederate-memorials; American Historical Association, "AHA Statement on Confederate Monuments (August 2017) | AHA," August 28, 2017, https://www.historians.org/news-and-advocacy/ statements-and-resolutions-of-support-and-protest/aha-statement-onconfederate-monuments; and Dell Upton, "Confederate Monuments and Civic Values in the Wake of Charlottesville," September 13, 2017, http:// www.sah.org/publications-and-research/sah-blog/sah-blog/2017/09/13/ confederate-monuments-and-civic-values-in-the-wake-of-charlottesville.

5 Charles S. Peirce, Philosophical Writings of Peirce, Selected and with an Introduction by Justus Buchler (New York,: Dover Publications, 1955), 102.

6 Hans-Georg Gadamer, Truth and Method (New York: Crossroad, 1989), 152-153.

7 Hermann Glaser, "The Majority Could Have Stayed away without the Risk of Repression," The German Public and the Persecution of the Jews, 1933-1945, ed. by Jörg Wollenberg and Rado Pribić (Atlantic Highlands, N.J: Humanities
Press, 1996): 15-21; 15-16. Glaser is quoting a reporter from the Fränkische Tageszeitung, November 11, 1938.

8 A number of exhibitions were brought to the building, including German Building Exhibition in 1949, 900 years of Nuremberg exhibit in 1950, and restaurant exhibition in 1951.

9 Hannah Arendt, "Eichmann in Jerusalem" I-V, The New Yorker, February 16 March 16, 1963.

10 Theodor W. Adorno, Critical Models: Interventions and Catchwords, European Perspectives (New York: Columbia University Press, 1998), 89. The lecture was originally titled "Was bedeutet: Aufarbeitung der Vergangenheit," and was given at a conference on education hosted by the Duetsche Koordinierungsrat der Gesellschaften für Christlich-Jüdische Zusammenarbeit (German Coordinating Council of Organizations for Christian-Jewish Cooperation) in Wiesbaden. on November 9, 1959, in Wiesbaden.

11 With the increasing willingness to confront Nazi crimes, in 1973, the Reichsparteipagsgelände were listed under the Bavarian State Historic Preservation Law.

12 Michael Petzet later became the President of the German National Committee of ICOMOS (1989-) and the President of ICOMOS International (1999 and 2008). See: "Michael Petzet, Advisor, Conservationist," "dOCUMENTA (13) - dOCUMENTA (13)," accessed May 25, 2017, http://d13.documenta.de/\#participants/ participants/michael-petzet/.

13 According to their idea, a small pavilion in the space between the two end blocks would inform visitors of the Nazi period and the history of the Nazi party Rally Grounds, and a path in the center of the courtyard fenced with barbed-wire would symbolically exclude National Socialism from their lives.

14 Competition program, section 2.

15 Franz Sonnenberger, "A City Confronts Its Past: Nuremberg's Documentation Centre on the Reich Party Congress Site; 1999," Museum International 51, no. 3 (July 1999): 53-57; 54, accessed May 25, 2017, http://www.unesco.org/ ulis/cgi-bin/ulis.pl?catno=116849\&set=0059274FF7_2_321\&gp=1\&lin=1 $\& \|=1$. For information on Franz Sonnenberger, see: "Nürnberger Museen-Chef Geht in Ruhestand," Nürnberger Nachrichten [Nuremberg News] (August 23, 2008), accessed July 19, 2017, http://www.nordbayern.de/cm/2.244/kultur/ nurnberger-museen-chef-geht-in-ruhestand-1.853649. See also: Nuremberg: The Imaginary Capital - Page 272; Sharon McDonald, p. 207.

16 Dürschinger \& Biefang; Frese \& Kleindienst; and Arbeitsgemeinschaft Hennig \& Mihm with Dietrich Lohmann from Nuremberg and its environ; Johannes Hölzinger from Bad Nauheim (north of Frankfurt); Architekten am Pündterplatz with Jörg Homeier and Gerold Richter from Munich; Johann Peter Kulka from Cologne; and Volker Staab from Berlin.

17 The second prize went to Johannes Hölzinger, and honorable mention to Volker Staab and Frese \& Kleindienst. Wettbewerbe Aktuell, March 1999, 44-45.

18 On September 16, 1998 as a part of a colloquium the City of Nuremberg organized for the invited competitors Presentation script, by Günther Domenig (November 15, 2000), Az-W. Competition program, page 14.

19 Others also acknowledged the new "surgical incision" in Deconstructivist style contrasting against the monumentality of the Nazi propaganda architecture. See, for example: pamphlet "Dokumentationszentrum Reichsparteitagsgelände," by the Nuremberg City Museums (2001), the section titled "Pfahl aus Glas und Stahl" [spear of glass and steel]; news release "Neues Dokumentationszentrum Reichsparteitagsgelände - eine nationale Aufgabe," by the Nuremberg City Museums (November 15, 2000); and news release "Neues Zeichen - Die Architektur des Dokumentationszentrum Reichsparteitagsgelände," by the Nuremberg City Museums (November 15, 2000), Az-W.

20 The descent is characterized as a kind of a "lock from the past to the present," referring to the device that controls water flow in a canal News release, by the Public Relations Office, Nuremberg City Museums (November 15, 2000), Az-W.

21 Press release, by Günther Domenig (October 31, 2001), Az-W.

22 Press release, by Günther Domenig (October 31, 2001), Az-W.

23 A set of drawings at the Domenig Archive show where the walls were to be cut. Walter Anderle, Nuremberg's City Master Planner, spoke about the difficulty: "The existing building materials - hard bricks and high-quality concrete - offered an unexpectedly great resistance to demolition work." "...the construction work was faced with the most difficult tasks. $2 \mathrm{~m}$ thick masonry work had to be cut through in different places. With diagonal penetrations, this increased to 5 m."Press release, by Walter Anderle (October 31, 2001), Az-W.

24 Gregor Schöllgen, "Speichern: In Der Kulisse Des Führers," Frankfurter Allgemeine Zeitung, April 7, 1998, sec. no. 82, page 44, https://fazarchiv.faz.net/ fazDocument/saveSingleDoc/FAZ__F19980407REICHSP100.

25 Press release, by the Public Relations Office, Nuremberg City Museums (November 15, 2000), Az-W.

26 Presentation script, by Günther Domenig (November 15, 2000), Az-W. 